\title{
ONLINE REPUTATION AND DESTINATION COMPETITIVENESS: THE CASE OF SPAIN
}

\author{
JOSÉ FRANCISCO PERLES-RIBES,* ANA BELÉN RAMÓN-RODRÍGUEZ,* \\ LUIS MORENO-IZQUIERDO,* AND MARÍA JESÚS SUCH-DEVESA†
}

*Department of Applied Economic Analysis, University of Alicante, Alicante, Spain

†Department of Economics, University of Alcalá, Alcalá de Henares, Madrid, Spain

\begin{abstract}
This article empirically explores the relationship existing between the online reputation and tourism competitiveness of Spanish coastal tourism destinations. It is based on big data from comments made by tourists in social media. The existing literature suggests that, in theory, a destination's online reputation plays a key role in promoting its competitiveness. However, the results obtained in this study reflect, for the Spanish case, that this effect is today still very small and other determinants of competitiveness exist that are more relevant in promoting a true competitive advantage of destinations.
\end{abstract}

Key words: Online reputation; Destination competitiveness; Social media; Tourist perceptions; Big data, Spain

Introduction

The success of tourism destinations in world markets heavily relies on their competitiveness (Komsic \& Dorcic, 2016), which nowadays depends on information and communication technologies (ICTs) that have strongly influenced the behavior of tourists, providing them with a wealth of information and increasing the range of possible choices and options (Buhalis, 2003; Buhalis \& Law, 2008; Inversini, Cantoni \& De Prieto, 2014).

One of the potential ways in which ICTs can affect the competitiveness of destinations is by enhancing their online reputation. Vengesayi (2003) proposed a conceptual model in which promotion (including reputation), branding, and pricing constitute drivers of destination competitiveness. A positive reputation enhances the competitiveness of a destination, favoring its attractiveness and therefore the potential demand to visit it (Komsic \& Dorcic, 2016). Consequently, tourist destinations dedicate a considerable amount of resources to improve their image (Hong, 2009) and, in this context, many destination management organizations (DMOs) are making a considerable effort to establish the destination's online reputation by monitoring electronic-wordof-mouth (eWOM) on social media sites (Zach, Marchiori, \& Cantoni, 2012). 
With the emergence of the paradigm of smart tourism destinations and the growth of the millennial segment of global tourism, it is expected that these efforts will be intensified, both by private initiatives and through public resources, which is why an in-depth analysis of the effectiveness of these activities is advised. Although the theory indicates that a destination's (online) reputation plays an inevitable role in increasing tourism demand and tourism destination competitiveness, there is currently no model quantifying the relationship between DMO actions and destination competitiveness (Pike \& Mason, 2011) and the gap in the literature is mainly concerned with empirical research (Komsic \& Dorcic, 2016).

This article seeks to fill this gap in the existing literature by exploring the relationship between online reputation and tourism competitiveness of Spanish coastal tourism destinations based on big data from comments of tourists on social media. To the best of the authors' knowledge, this is the first attempt to test this relationship for the Spanish case.

The article is structured as follows. The second section comprises a review of the literature on brand reputation and competitiveness and states the hypotheses to be tested. The third section describes the methodology and data used. The fourth section presents the results and the findings and limitations of the study are discussed. Finally, future lines of research are suggested in the fifth section.

\section{Literature Review: Online Reputation, Tourism Brand, Destination Image, and Tourism Competitiveness}

Figure 1 reflects the relationships between reputation, the image of the destination, and its competitiveness. The reputation (both online and offline) promoted through branding and marketing techniques contributes to the improvement of the image of the destination. This improvement in the destination's image, through the increase in demand generated, enhances the competitiveness of the destination. However, at the same time, the image of a destination is affected by its own competitiveness in terms of the quality of the basic and advanced resources available in the destination and the performance of the tourism industry existing there, which favors, to a greater or lesser degree, the tourist experience of visitors.

The literature review subsections follow the structure of Figure 1 from right to left. The first subsection addresses the definition and measurement of competitiveness. The second subsection discusses the destination image as a source of tourism competitiveness. In the third subsection, the relationship between destination image and online reputation is reviewed. Finally, the middle part of Figure 1 is explored by analyzing the one-way or two-way relationship existing between destination image and competitiveness.

First, a note of clarification should be made regarding the use of the terms online reputation, image of destinations, and branding in the following sections. These terms are not interchangeable. The literature on competitiveness and the literature on marketing and branding of destinations are not completely connected. For this reason, the term image of destination is mainly used in the competitiveness subsections of the literature review, as the competitiveness literature considers destination image or branding as a source of competitiveness, but, to date, has not considered online reputation in the models, probably due to the novelty of this
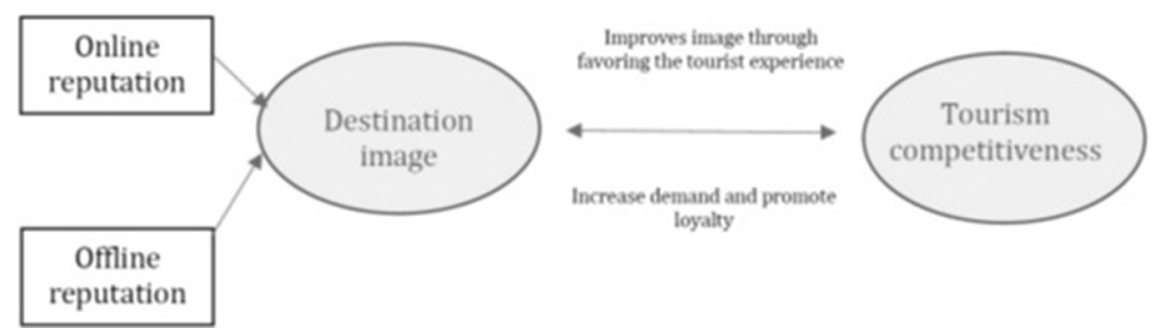

Figure 1. Conceptual model for the relationship between online reputation and tourism competitiveness. Authors own elaboration. 
term. Conversely, destination image and branding usually appear together with online reputation in the literature on marketing and the use of new technologies in tourism promotion. Therefore, each term has its own meaning and contributes in its own measure to the explanation and development of the model presented.

\section{Tourism Competitiveness:}

Definition and Measurement

According to Dwyer, Forsyth, and Dwyer (2010), competitiveness materializes price differentials (adjusted by exchange rates), productivity of the tourist industry, and qualitative factors affecting the attractiveness of a destination. Applied to tourist destinations, "competitiveness refers to the capacity of a destination to provide goods and services that are more highly valued by tourists than those offered by competitors" (Dwyer \& Kim, 2003, p. 275).

There are many explanatory models of tourism destination competitiveness (the most relevant being the models proposed by Buhalis, 2000; Crouch \& Ritchie, 1999, updated by Crouch, 2011; Dwyer \& Kim, 2003; Hassan, 2000; Heath, 2003, Poon, 1993) that encompass a wide range of competitive and comparative advantages and have refined the original model of Porter (1990).

Perles, Ramón, Rubia, and Moreno (2016) pointed out the difficulties in measuring tourism competitiveness, in the absence of a globally accepted model of measurement (Omerzel \& Mihalic, 2008). D'Hauteserre (2000), for example, used market share as a measure of destination competitiveness. However, adopting market share as an indicator of competitiveness is highly disputed (see Croes, 2011; Crouch \& Ritchie, 1999, Enright \& Newton, 2004, for criticism about the use of this measure) Authors such as Perles, Ramón, and Sevilla (2014) defended the use of market share as an indicator of competitiveness in studies that analyze a broad timeframe for which there are no other available indicators.

Given the difficulties in accepting market share as an indicator of competitiveness, other alternatives have arisen. For example, as noted in Perles, Ramón, and Sevilla (2011), Kozak and Rimmington (1999) measured competitiveness using data gathered from surveys on the perceptions and opinions of tourists, capturing the demand viewpoint of competitiveness. In addition, authors such as Papatheodorou (2002) or Perles et al. (2011) used published data to provide a supply point of view. However, according to Gooroochurn and Sugiyarto (2005), tourism competitiveness is generally measured using synthetic indicators, the most successful being the Tourism and Travel Competitiveness Index, published by the World Economic Forum (2015). In Spain, an adaptation has been developed (MoniTUR) for the different Spanish regions that is carried out by the employer's association of the Spanish tourism industry, Exceltur.

\section{The Image of the Destination \\ in Competitiveness Models}

A review of the most commonly accepted competitiveness models of tourism destinations revealed that the image of tourism destinations is, in general, considered as an element that conditions the competitiveness of destinations but does not form part of their core determinants, which are made up of their basic and advanced factors.

Strictly speaking, Porter (1990) did not analyze the competitiveness of tourism, which is why he did not expressly use the image of the tourism destination as a determinant of competitiveness. However, it seems obvious that this image, although conditioned by the basic factors (natural resources, climate, landscape) and advanced factors (formation of human resources and advanced institutions) of the destination, is fundamentally related to the conditions of demand in Porter's diamond due to its capacity to affect it. In this respect, it would be difficult to attain the volume of demand established by Porter to improve the competitiveness of the destination if it does not have an image that is minimally accepted by this demand.

This relationship between the image of the destination and the aspects of demand is acknowledged in the models of tourism competitiveness that have emerged after Porter (1990). For example, in the model proposed by Crouch and Ritchie (1999) the awareness and brand image of the destination are included in the determinants that extend and improve competitiveness together with location, interdependencies (ties between origins and 
destination), health and safety, and the quality/ price ratio offered by the destination. In the integrated model of competitiveness created by Dwyer and Kim (2003), the awareness and image of the destination are included among the demand conditions together with the preferences of tourists. This model recognizes a two-way causal link connecting created resources (attributes such as tourism infrastructure, special events, the range of available activities, entertainment, and shopping) and supporting factors (general infrastructure, quality of service, accessibility of destination, hospitality, and market ties) to demand and to destination management. The image of the destination also constitutes a determinant of competitiveness in subsequent adaptations of this model, such as Dwyer, Liavic, and Mellor, (2003).

In Hassan's (2000) study, who emphasized the environmental aspects of competitiveness, the image of the country and environmental marketing incorporates a determinant of competitiveness called the destination's commitment to the environment. Heath (2003) included the positive image of the destination in the determinant of competitiveness called destination strategy and marketing together with target marketing and demand management, the existence of innovative marketing, and tourist satisfaction. Kim and Lee (2005) considered tourism attractiveness as a qualitative source of competitiveness, which includes the image of the destination.

Among the more recent contributions, Mika (2012) proposed a competitiveness model in which the overall image of a destination based on tourist opinions forms part of the first stage in the evaluation of the destination's state of development. Oh, Kim, and Lee (2013) developed a model and a scale for evaluating the intercountry competitiveness of tourism destinations that includes the reputation of tourism companies, the brand image of tourism products, and the national brand competitiveness among the sources of destination competitiveness.

However, Vengesayi (2003) proposed that these two concepts should be analyzed within an integrated framework. According to this author, the popularity of tourism destinations can be enhanced through a combination of the factors of competitiveness and attractiveness. The competitiveness elements are derived from the supply side and the attractiveness from the demand side of tourism. Within this framework, this author proposed a conceptual model in which promotion (including reputation), branding, and pricing moderate the relationship existing between destination competitiveness and attractiveness.

Therefore, the literature review reveals that the principal existing competitiveness models acknowledge that image plays a role in enhancing the competitiveness of tourism destinations. However, despite the importance of the image of the destination in the conceptual models of tourism competitiveness, there is a lack of empirical research that substantiates this relationship (Miličevič, Mihalič, \& Server, 2016).

\section{Image of Destinations and Online Reputation: The Emergence of New Technologies}

The emergence of the Internet has changed the way in which tourists communicate and interact with destinations. According to Govers, Go \& Kumar (2007), in previous decades a unilateral communication from destinations and firms to tourists based on traditional methods and tour operators prevailed in the market. However, today tourists have changed their behavior and obtain real-time information from social networks, which influences their travel decisions (Miguéns, Baggio, \& Costa, 2008). Thus, the Internet has inverted the position of the user in the tourism value chain by modifying the distribution of the product (Berne, García-González \& Mugica, 2012; Govers \& Go, 2003; Rita, 2000). All of this user-generated content (Akehurst, 2009; Filieri, 2015; Marine-Roig \& Clavé, 2015) configures the online reputation of destinations. In this sense, digitalization has led to a loss of control of the brand image of destinations, which now depends on customer reviews (Edleman, 2010).

The relationship between the online reputation and the competitiveness of a tourism destination has hardly been addressed in the existing literature. Several studies can be found in the literature that analyzed the relationship between online reputation and firm performance at a business level (e.g., Rodríguez-Díaz \& Espino-Rodríguez, 2018), but studies with respect to destinations are very scarce.

In general, it is acknowledged that reputation is highly useful to improve competitiveness 
(Pechlaner, Smeral, \& Matzier, 2002). Authors such as Caldwell and Freire (2004) or De Moya \& Jain (2013) pointed out that this reputation partly explains final competitiveness and suggested that competitiveness and reputation mutually influence one another. Similarly, Marchiori and Cantoni (2011) emphasized that online reviews and the subjective experiences of travelers could affect visits to a destination. Finally, different authors such as Gallarza, Gil-Saura, and García (2002), Pike (2002), or Zhang, Fu, Cai, and Lu (2014) conducted literature reviews on the reputation of tourist destinations, highlighting the relevance of this reputation for tourist satisfaction and destination competitiveness.

ICTs strongly influence marketing and branding. Destinations go to great lengths to project their image through social networks by creating viral messages to capture new tourists (Amersdorffer, Bauhuber \& Oellrich, 2012; Di Pietro, Di Virgilio \& Pantano, 2012; Garay \& Cànoves, 2016; Gretzel \& Yoo, 2008; Singer, Ferri, Aiello \& Cacia, 2010). This coincides with the findings of Leung and Law (2006), who observed that the impact of social networks is, by far, the element most studied by researchers. The rationale behind all of these efforts is to enhance the destination's reputation, which influences the decisions of tourists and stakeholders. The image of a destination is perceived as being a highly reliable indicator because it is conveyed by tourists' peers and is not driven by an economic interest to improve the destination's competitiveness (Marine-Roig \& Clavé, 2015).

Similarly, since 1995, regional and local governments have been using their own websites to reinforce their brand image (Han \& Mills, 2006), leading many researchers to focus their studies on analyzing the websites of destinations to evaluate their attractiveness, usefulness, and the impact they have on tourists (Law, Qi, \& Buhalis, 2010). This process is usually led by the governments creating official websites to define and promote brand image strategies, although they have been reinforced by private sector companies in the destination and their corresponding websites (Horng \& Tsai, 2010). However, as noted by Akerhurst (2009), travelers prefer the comments of other people in social networks rather than images, and they prefer opinions in blogs to the official news, which justifies the efforts of DMOs in promoting their online reputation through social networks.

Finally, other technological elements related to the concept of smart destination, such as mobile phones and applications, have a high capacity to promote the reputation of tourist destinations (Berger, Lehmann, \& Lehner, 2003; Brown \& Chalmer, 2003; Werthner, 2003). According to Dickinson et al. (2014), these mobile devices enable tourist destinations to better adapt their supply to demand in real time, favoring the tourist experience and improving the online reputation of destinations.

However, it is also true that not all tourists value online platforms and applications equally when choosing a destination. According to Neuts, Romão, Nijkamp, and Van Leeuwenn (2013), today a clear segmentation exists, with the younger tourists making a more intense use of applications and web services to obtain information and interact in the places that they visit. For this reason, the success of destinations in the future is expected to depend on a modernization of infrastructures, the provision of more and better information and communication channels with visitors, and the so-called knowledge and smart destinations (Buhalis \& Amarnggana, 2014; Gretzel, Werthner, Koo, \& Lamsfus, 2015; Stamboulis \& Skayannis, 2003).

\section{Competitiveness, Reputation, and Online Reputation of Tourist Destinations: A Bilateral Relationship?}

In conclusion, a review of the existing literature finds a direct relationship between the reputation or image of a destination and its competitiveness. The exact direction of this relationship remains to be discussed, although this article defends its bilateral nature in accordance with the model proposed by Dwyer and Kim (2003) (see Fig. 1). On the one hand, it seems obvious that a destination's image is based on those attributes of the destination that form the basis of its competitiveness. If the basic conditions of a destination are not acceptable for the demand, it is very difficult, however advanced the marketing techniques used, to portray a positive image of the destination that is valued by the tourism demand. This difficulty has increased in recent years with the emergence of communication technologies and the immediacy with which 
tourists, through social networks, are able to condition and position the image of tourist destinations. On the other hand, a positive image of the destination and a good online reputation can favor the demand conditions - in terms of both volume and the level of understanding and requirement of the demand - that constitute a basic determinant of tourism competitiveness (Assaker, Hallak, Assaf, \& Assad, 2015).

In view of these considerations, the existence of a bilateral or two-way relationship between the image or reputation of tourist destinations and their competitiveness is the most plausible hypothesis. However, in this context, and considering the lack of more and better data to test this causal relationship, the hypotheses that are tested in this article is whether an association exists between the online reputation of Spanish destinations and their competitiveness. Or, expressed in statistical terms:

H0: No relationship exists between online reputation and competitiveness for the case of Spanish tourist destinations.
H1: A relationship exists between online reputation and competitiveness for the case of Spanish tourist destinations.

In the following sections the hypotheses will be tested.

\section{Methodology and Data}

The online reputation data for the Spanish coastline destinations have been provided by Socialvane (2016) based on big data from 8,631,510 comments on Twitter and Instagram relating to the Spanish coastal brands shown in Table 1 from July 1 to August 31, 2015. Socialvane "is a company specialized in the extraction of market intelligence for the tourism sector from the analysis of massive volume of social data" (Socialvane, 2016, p. 4). ${ }^{1}$ The use of secondary data sources based on market intelligence or industry reports is not uncommon in scientific publications related to ICTs in tourism (see, e.g., Cosma, Bota, \& Tutunea, 2012; Hays, Page, \& Buhalis, 2013, for recent use).

Table 1

Spanish Coastal Brands

\begin{tabular}{|c|c|c|}
\hline Coastal Brand & Province (NUTS 3) & Region (NUTS 2) \\
\hline $\begin{array}{l}\text { Menorca } \\
\text { Ibiza } \\
\text { Mallorca }\end{array}$ & Balearic Islands & Balearic Islands \\
\hline Costa Euskadi & $\begin{array}{l}\text { Biscay } \\
\text { Guipuzcoa }\end{array}$ & Basque Country \\
\hline Fuerteventura & Las Palmas & Canary Islands \\
\hline Costa del Sol & Malaga & Andalusia \\
\hline Costa de la Luz & Cadiz & \\
\hline Costa de la Luz & Huelva & \\
\hline Costa de Almeria & Almeria & \\
\hline Tenerife & Tenerife & Canary Islands \\
\hline $\begin{array}{l}\text { Gran Canaria } \\
\text { Lanzarote }\end{array}$ & Las Palmas & \\
\hline Costa de Galicia & Lugo & Galicia \\
\hline Costa de Galicia & A Coruna & \\
\hline Costa de Galicia & Pontevedra & \\
\hline Costa de Asturias & Asturias & Asturias \\
\hline Costa Blanca & Alicante & Region of Valencia \\
\hline Costa de Valencia & Valencia & \\
\hline Costa de Azahar & Castellon & \\
\hline Costa de Cantabria & Cantabria & Cantabria \\
\hline Costa Calida & Murcia & Murcia \\
\hline Costa Daurada & Tarragona & Catalonia \\
\hline Costa Barcelona & Barcelona & \\
\hline Costa Brava & Gerona & \\
\hline
\end{tabular}


Regarding the social networks used in the study, Twitter and Instagram are two of the most relevant social networks used in Spain. According to Statista (2018), Twitter (16.68\%) ranked second among the social media used in Spain in 2016, behind Facebook (28.79\%) and ahead of YouTube (11.72\%). Twitter has also been considered by previous literature on the topic (e.g., Hays et al., 2013, on the use of social networks by national tourism organizations or Milano, Baggio, and Piattelli, 2011, on the effects of social media on tourism websites).

With regard to Instagram, in 2016 it held the fifth position in the ranking. However, this social network is growing rapidly among tourists and in 2017 it reached a share of $10.87 \%$, surpassing Linkedin and gaining the fourth position in the ranking.

It is worth noting that this is the first time in Spain that this type of data drawn from the comments of tourists on social networks has been available and used to study destination competitiveness. Social media data are increasingly used to analyze user perception and online reputation in tourism (Leung, Law, Van Hoof \& Buhalis., 2013; Munar \& Jacobsen, 2013, 2014; Sigala, 2011). All mentions regarding Spanish coastal destinations in the following languages have been gathered and analyzed: Spanish, English, French, Portuguese, German, Italian, Norwegian, and Catalan.

Table 1 shows the correspondence between the tourism brands, regions, and provinces analyzed. The most commented Spanish coastal destination on social networks during July and August 2015 was, by far, Ibiza (1,313,233 mentions), followed by the Costa del Sol (943,172 mentions), the Costa de la Luz (745,973 mentions), and the Costa Blanca (742,363). On the other hand, the least commented destination was the Basque coast with 27,967 mentions (Socialvane 2016).

Socialvane (2016) does not provide details regarding the exact construction of the indicators of reputation and simply indicates that the data are processed by using an algorithm developed by the company, which enables comments that are particularly relevant and sensitive for the tourism activity of the destinations to be identified. Socialvane has developed five indicators of online reputation with values of between 0 and 100 .

The first indicator, the tourism product index, seeks to measure the satisfaction associated to the overall supply of a destination by relating the most quantitative element of a tourism product, namely the number of times it is mentioned, with the most qualitative element, which is the associated feeling. This is a key measurement, given that it reveals the importance of each product in a destination based not only on its share but also on the satisfaction associated to it (Socialvane, 2016). The average value of the index for Spanish destinations is 63.22 with the leader being Fuerteventura (71.47) and Lanzarote holding the last place of the ranking (58.10). Attributes such as natural and tourist attractions, cultural attractions, comfort facilities, atmosphere, and how they affect tourist satisfaction have been used previously in the literature (Prayag, 2008; Rajesh. 2013). The second indicator, perceived safety, measures the degree of safety perceived by tourists in a specific destination, producing an average value for Spain as a whole of 88.91, with Menorca at the top of the ranking (99.48) and the Costa de Cantabria (70.76) at the bottom. Attributes such as safety are also used as a measure of satisfaction of tourists (Rajesh, 2013).

The third indicator is the climate perception index which refers to the complaints made in relation to the climate in a specific destination in an inverse relationship: the fewer the complaints, the higher the value of the index. This index highlights the importance that the management of tourists' expectations can have in many destinations. The average value for Spain is 81.72 with Menorca at the top of the ranking (95.53) and the Costa de Azahar at the bottom (54.58). Tourist perceptions of weather are used as key attributes for tourism satisfaction (see, e.g., Beerli \& Martin, 2004; Chi \& Qu, 2008; Martin, Jacobsen \& Martin, 2011; Sonmez \& Sriakaya, 2002, among others).

The fourth indicator, associated reputation, seeks to determine the reputation of the tourist destination, taking into account all of the comments made by visitors on social networks. The average reputation of Spanish destinations is 65.16, with Menorca having the highest score (82.23) and the Costa Daurada with the lowest (46.02). Prayag and Ryan (2011) provided a basis on which to construct this type of indicator.

Finally, the fifth indicator, the Index of Tourist Perception (GTP) that attempts to measure the overall satisfaction of the tourist with the 
destination, goes far beyond the classic concept of reputation and takes into account and weights the four previous indexes (the tourist products index, the perceived safety index, the index of climate perception, and the associated reputation index) that measure different elements relevant for choosing a holiday destination (Socialvane, 2016). This fifth indicator is used in this study (see Fig. 2) to estimate the relationship between competitiveness and online reputation, on the grounds that it is the most comprehensive. Destination image, personal involvement, and place attachment influence the satisfaction of tourists (Prayag \& Ryan 2011). This indicator seems to be adequate because attributes such as perceived attractions, perceived quality, perceived risk, perceived value, safety, and infrastructure are used as measures of the satisfaction of tourists.

On the other hand, destination competitiveness is proxied by two variables. The first is more related to the multidimensional nature of tourism destination competitiveness (Spence \& Hazard, 1988), namely the MoniTUR Index (Exceltur, 2015) for the year 2014 (the latest available). MoniTUR is a pioneering initiative that comprehensively approximates the relative competitive position of the tourist supply of the 17 Spanish regions (NUTS 2). Through 80 objective indicators grouped into seven pillars (Strategic marketing plan vision and business support; Accessibility and connectivity; Planning and competitive determinants of the destination; Diversification and structure of products; Talent attraction, education and human resources efficiency; Policy priority and tourism governance and Economic and social performance), MoniTUR evaluates the capacity of each region to consolidate a differentiated and sustainable tourism positioning over time that conciliates and ensures greater economic prosperity, job creation, and perceived well-being of tourism at the local level, with the best value and preservation of their identity values and their natural, cultural, and territorial resources (Exceltur, 2015).

The use of this indicator to reflect the competitiveness of Spanish tourism destinations is justified, as mentioned above, as it is an adaptation of the well-known Tourism and Travel Competitiveness Index published World Economic Forum (2015) to the Spanish case. In MoniTUR, the value of 100 represents the average competitiveness of the Spanish regions, with a range varying between 116.0 for Catalonia as the leader (see Fig. 3) and 90.3 corresponding to Extremadura, which is at the bottom of the ranking. Navarra (100.1), La Rioja (100.1), Galicia (100.0), and Castilla León (99.8) all produce values close to the average.

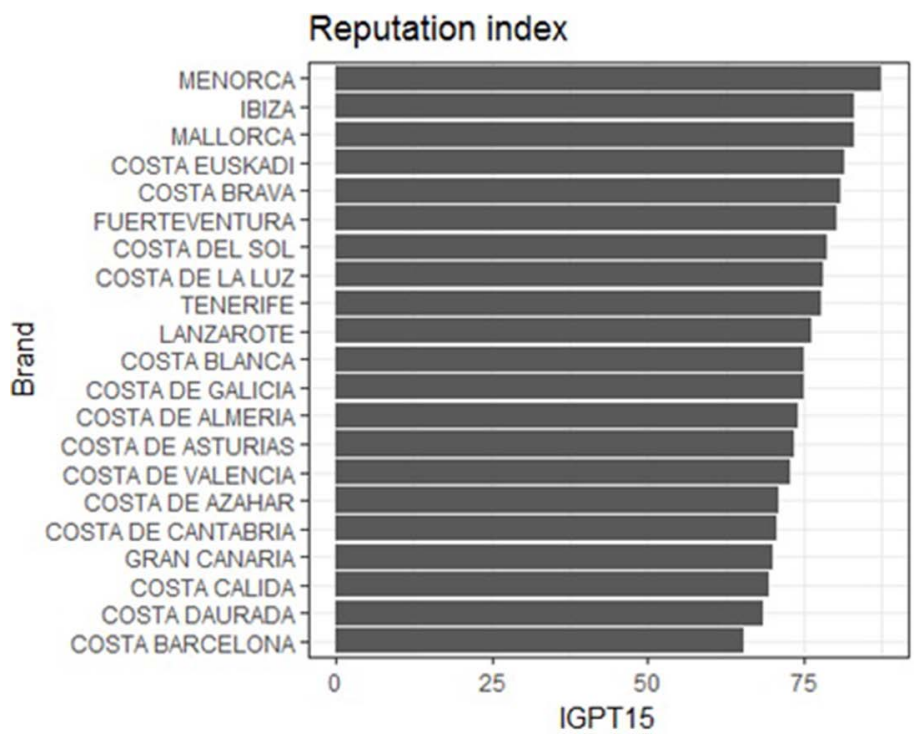

Figure 2. Online reputation of Spanish tourism destinations 2015. 


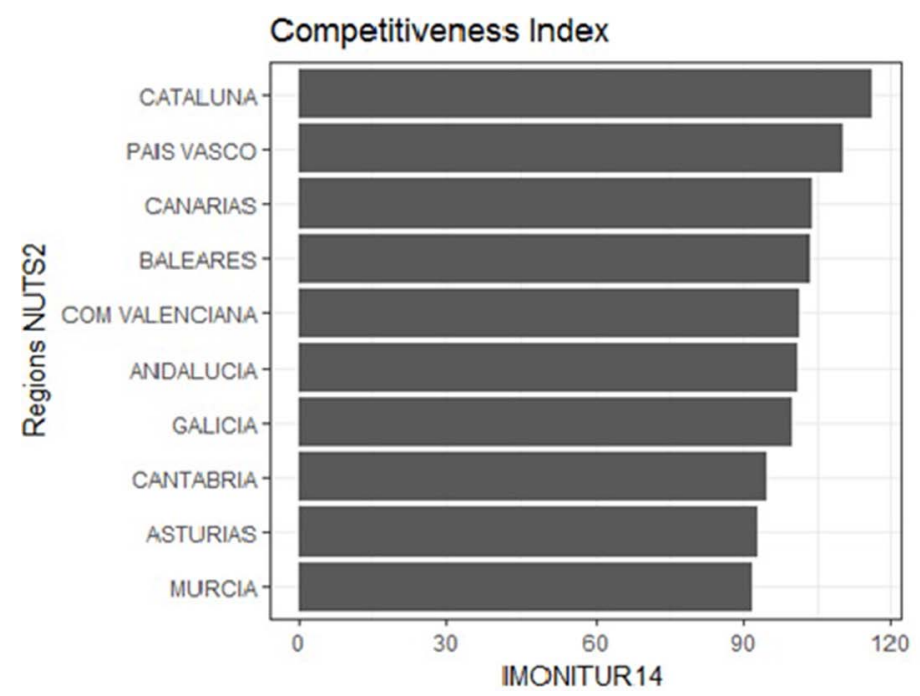

Figure 3. Competitiveness index MoniTUR of Spanish tourism destinations 2014.

Apart from the indicator provided by MoniTUR, and to gain a broader vision of competitiveness, more related to the original conceptualization of Porter (1990) and Crouch and Ritchie (1999) and of the relevance that the well-being of the local society plays in this concept, in this article another proxy for destination competitiveness - in the absence of other well-being indicators for this territorial level-is the per capita income of the provinces (NUTS 3) considered, provided by the Spanish Statistical Institute (Instituto Nacional de Estadística [INE], 2016). In fact, according to the methodology used in the World Economic Forum's Global Competitiveness Index (GCI), about two thirds of the variation in the competitiveness index can be explained by GDP per capita. The data for the year 2014, the latest available, are used (see Fig. 4).

It should be noted that both of the competitiveness indexes display a high level of stability in terms of values and the ranking positions of regions and provinces over time, so the values for 2014 of both competitiveness indexes contemplated in the analysis could be considered as good proxies for their values in 2015, matching the values of online reputation.

To analyze the relationship existing between the online reputation and competitiveness of Spanish tourist destinations, the degree of the tourism specialization of the different destinations analyzed has been used as a control variable. La Caixa
(2014) provides a tourism specialization index of destinations based on the participation of each municipality, province, or region in the tax earned from economic activities corresponding to the tourist activities on a national basis of 100,000 units for the whole of Spain. The objective of this index is to control the relevance of the tourism industry in the destinations.

Regarding the methodology, the relationship between online reputation and competitiveness is visually inspected through scatterplots among the variables and analyzed by Ordinary Least Square regression using competitiveness as the dependent variable and the online reputation and the tourist specialization index provided by La Caixa (2014) (see Figs. 5 and 6) as explanatory variables. The exploratory nature of this article and the initial lack of linear association between the variablesbasically due to the scarcity of observations $(n=25)$ - do not allow the whole of the regression analysis carried out to be expressed, which, however, is available to readers upon request.

Apart from the scarce sample size, the statistical significance for regression parameters is very difficult to obtain without the existence of a big effect size which, in principle, is not expected. This expectation is based on the relative newness of online reputation as a source of tourism competitiveness, which probably partially affects the demand for 


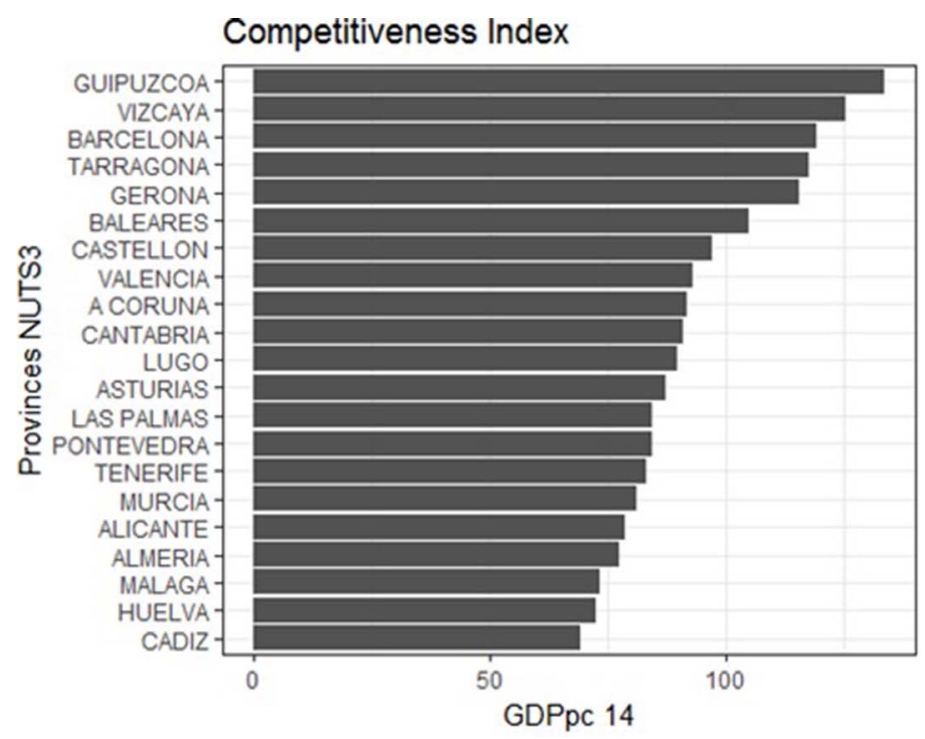

Figure 4. Competitiveness GDP per capita of Spanish tourism destinations 2014.

tourist destinations (the youngest segment of the demand) that uses the Internet and social networks more intensely. In any case, this result should be confirmed, as more and better data on the variables considered in the analysis for a wider set of tourist destinations become available.
Results

The exploratory analysis of the data reveals that normality distribution can be assumed for the variables of the online reputation index and GDP per capita in the provinces NUTS 3, but not for the

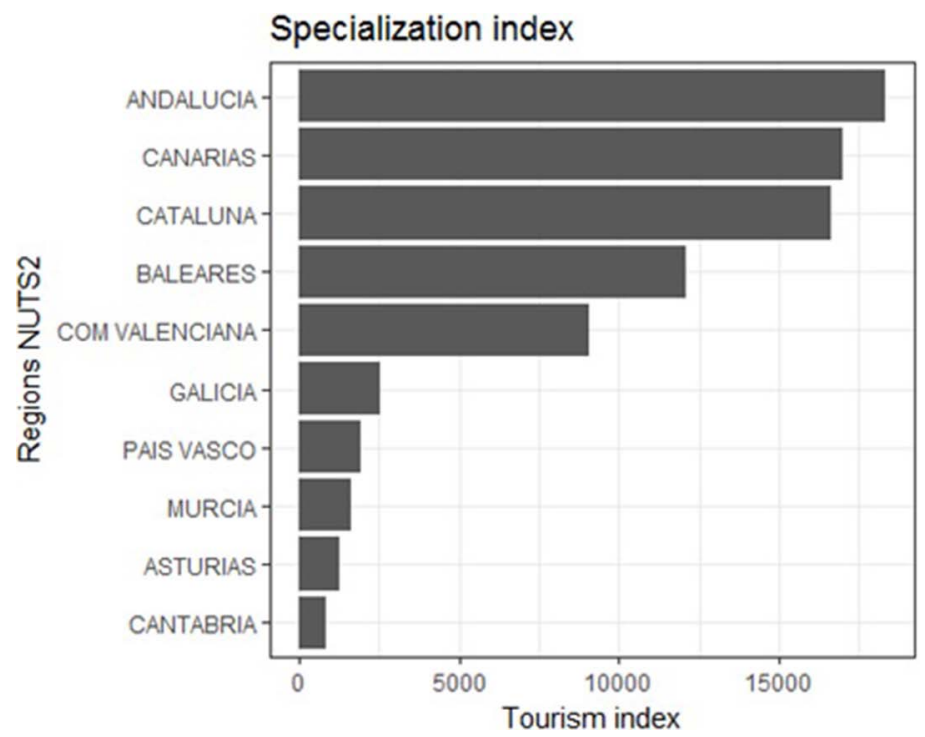

Figure 5. Tourism specialization index of Spanish tourism destinations 2013. 


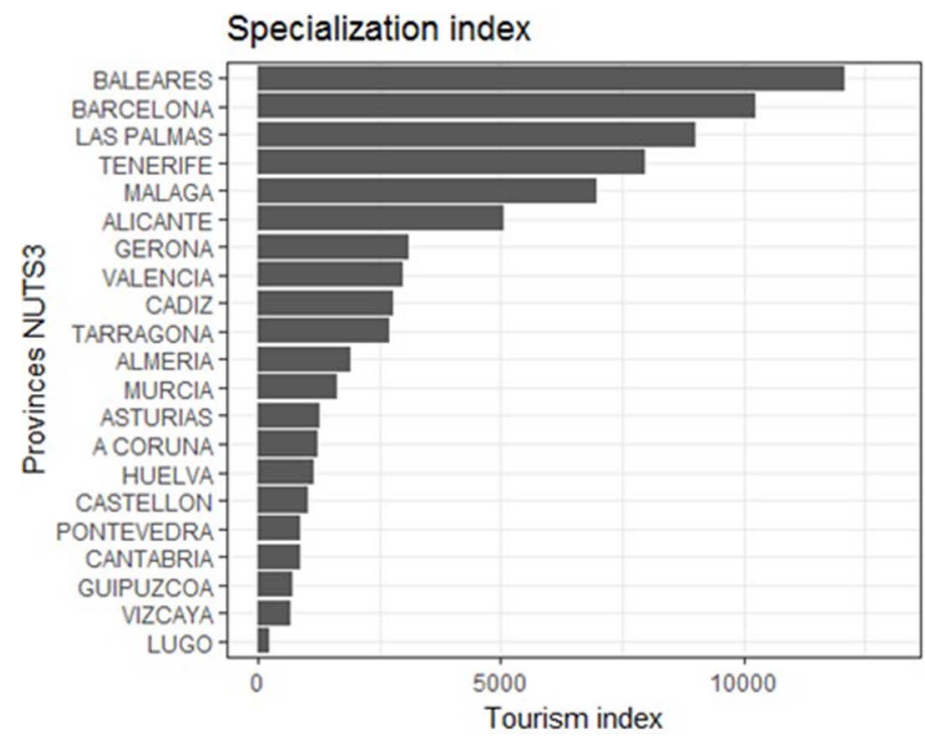

Figure 6. Tourism specialization index of Spanish tourism destinations 2013.

MoniTUR competitiveness index where several outliers exist, nor for the GDP per capita in the case of the regions (NUTS 2). The scatterplots among the variables (Fig. 7) reveal a positive but very low linear correlation (and statistically not significant) between the online reputation index and the variables reflecting competitiveness in the case of regions NUTS 2 and the same for the case of provinces NUTS 3 with a Pearson correlation of 0.150 (Fig. 8).

The regressions performed confirm that despite the lack of statistical significance, there is no major concern here as the whole population of coastal destinations is considered and the point estimate parameter for the online reputation variable is positive. However, its influence on competitiveness is low as reflected by its standardized coefficient, which is lower than the parameter associated with the specialization index of destinations.

Thus, the results obtained reveal that, at least for the Spanish case, if the online reputation of tourist destinations affects their competitiveness, it does so today to a very small degree.
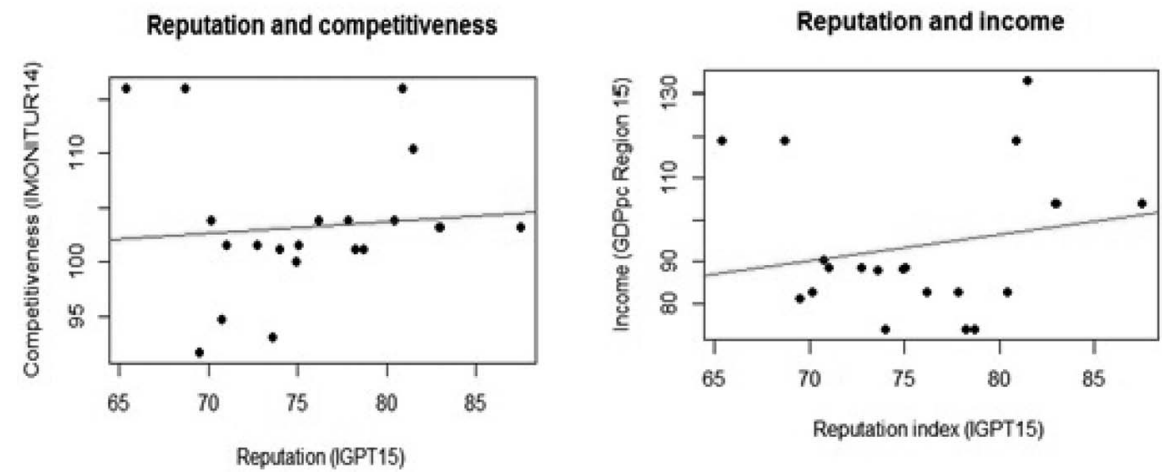

Figure 7. Relationship between online reputation index and competitiveness indexes in regions NUTS 2. Left: Scatterplot between online reputation index and moniTUR competitiveness index. Pearson correlation 0.0876. Right: Scatterplot between online reputation index and GDP per capita in regions in 2015. Pearson correlation 0.186. 


\section{Reputation and income}

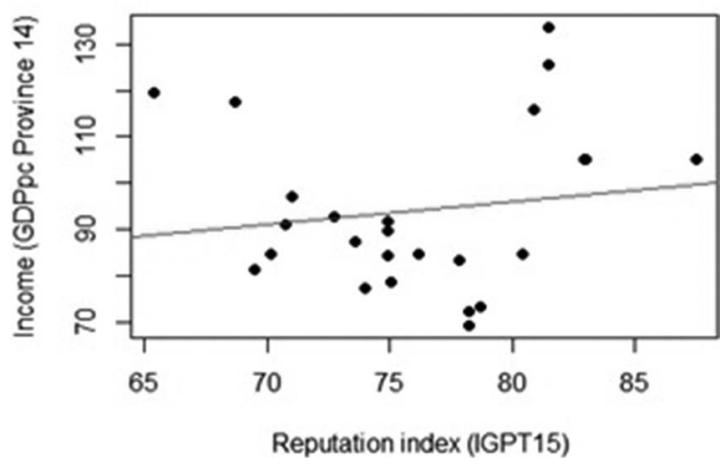

Figure 8. Relationship between online reputation index and GDP per capita in provinces NUTS 3.

\section{Discussion}

This article empirically explores the relationship existing between online reputation and tourism competitiveness in Spanish beach tourism destinations. The existing literature suggests that, in theory, a destination's online reputation plays a key role in promoting its competitiveness. However, the results obtained reflect, for the Spanish case, that this effect is today still very small and other determinants of competitiveness exist that are more relevant in promoting a true competitive advantage of destinations.

In view of the result obtained, a review (in a theoretical sense) of the causality relationship between the two variables could be considered. In this way, it should be contemplated whether a good online reputation, through an increase in demand, reinforces the competitiveness of a destination, or, on the contrary, whether it is the good previous level of competitiveness of a destination that enables tourists to enjoy good experiences that they transmit through their positive comments on social media, thereby improving the destination's online reputation. Finally, the causality relationship could be evaluated to determine whether it is bilateral, with the two phenomena mutually reinforcing one another, leading to a better performance of the destination in the tourism market.

However, to confirm these questions, the limitations faced by the authors of this article must first be overcome. The most important of these is the small sample size available for the analysis. This fact limits the quality of the regression by limiting the potential explanatory variables considered. Only the publication of new data in successive years for these same destinations, or the publication of data for other destinations (municipalities or other countries) will improve the quality of the estimates found in this study that today merely constitute an exploratory exercise. The suggestion for this line of research constitutes an innovation of this article in itself.

Similarly, the lack of a relationship between the online reputation and competitiveness of a destination could be attributed to the indicators (proxies) used to measure variables, competitiveness and online reputation.

This is the case of the competitiveness variable, particularly when the provincial (or NUTS3) GDP per capita is used, which can be affected by many different factors other than online reputation. The construction of real indicators of tourism competitiveness on a provincial level, either designed expressly or by territorializing regional indicators such as MoniTUR, seems advisable in view of the results obtained in this study. The improvement of these indicators, or the use of other alternatives such as market share, could shed more light on the relationship existing between the two variables.

On the other hand, with regard to the measurement of online reputation, either the two social networks selected for calculating the indicator, Instagram and Twitter, are not used as a reference by travelers (a hypothesis with a low probability), or the algorithms used for constructing the online reputation indicator based on user comments are not appropriate (a hypothesis that the authors cannot test with the available information). Therefore, the improvement in the indicators for measuring competitiveness, particularly online reputation, is another innovation proposed by this article.

In addition, this result suggests that the traditional brand image of a destination may not be exactly the same as its online reputation. Therefore, additional factors may exist, other than reputation, that influence the image a tourist has of a destination. Second, the demand for travel may be segmented into different user profiles; therefore, online reputation is only relevant for consumers who are familiar with technology. Lastly, it may be necessary to rethink whether the simple transfer of theories designed for 
the offline world to the online world with no adaptation is possible or whether the theories should undergo a much more thorough modification before their transfer. This represents a further innovation of the article.

It seems clear, therefore, that with a view to the future, this type of study will proliferate as new and improved indicators emerge, which will probably occur in line with the implementation and analysis of big data in tourism.

In any case, it is expected that in the medium term, online reputation will become a key determinant in the competitiveness of destinations, as consumers and younger tourists who use ICTs intensely are gaining a greater presence on the tourism demand scene.

\section{Note}

${ }^{1}$ The original URL for the Socialvane reference is no longer functional and the URL now contains a summary of the information. A pdf of the full document can be obtained from the corresponding author upon request.

\section{References}

Akehurst, G. (2009). User generated content: The use of blogs for tourism organisations and tourism consumers. Service Business, 3(1), 51-61.

Amersdorffer, D., Bauhuber, F., \& Oellrich, J. (2012). The economic and cultural aspects of the social web Implications for the tourism industry. Journal of Vacation Marketing, 18(3), 175-184.

Assaker, G., Hallak, A., Assaf, A. G., \& Assad, T. (2015). Validating a structural model of destination image, satisfaction, and loyalty across gender and age: Multigroup analysis with PLS-SEM. Tourism Analysis, 20(6), 577-591.

Beerli, A., \& Martin, J. D. (2004). Factors influencing destination image. Annals of Tourism Research, 31(3), 657-681.

Berger, S., Lehmann, H., \& Lehner, F. (2003). Locationbased service in the tourist industry. Information Technology \& Tourism, 5, 243-256.

Berne, C., García-Gonzalez, M., \& Mugica, J. (2012). How ICT shifts the power balance of tourism distribution channels. Tourism Management, 33(1), 205-214.

Brown, B., \& Chalmer, M. (2003). Tourism and mobile technology. In K. Kutti, E. Karsten, G. Fitzpatrick, P. Dourish, \& K. Schmidt (Eds.), Proceedings of the Eight European Conference on Computer Supported Cooperative Work (pp.335-354). Norwell, MA: Kluwer Academic Press.

Buhalis, D. (2000). Tourism in an era of information technology. In B. Faulkner, G. Moscardo, \& E. Laws (Eds.),
Tourism in the 21st century: Lessons from experience (pp.7-32). London, UK: Continuum.

Buhalis, D. (2003). ETourism: Information technology for strategic tourism management. Harlow, UK: Financial Times Prentice Hall.

Buhalis, D., \& Amaranggana, A. (2014). Smart tourism destinations. In Z. Xiang \& I. Tussyadiah (Eds.), Information and communication technologies in tourism 2014 (pp. 553-564). Dublin, Ireland: Springer.

Buhalis, D., \& Law, R. (2008). Progress in information technology and tourism management: 20 years on and 10 years after the Internet-The state of eTourism research. Tourism Management, 29(4), 609-623.

Caldwell, N., \& Freire, R. J. (2004). The differences between branding a country, a region and a city: Applying the brand box model. Journal of Brand Management, 12(1), 50-61.

Chi, C. G. Q., \& Qu, H. L. (2008). Examining the structural relationships of destination image, tourist satisfaction and destination loyalty: An integrated approach. Tourism Management, 29(4), 624-636.

Cosma, S., Bota, M., \& Tutunea, M. (2012). Study about customer preferences in using online tourism products. Procedia Economics and Finance, 3, 883-888.

Croes, R. (2011). Measuring and explaining competitiveness in the context of small island destinations. Journal of Travel Research, 50(4), 431-442.

Crouch, G. I. (2011). Destination competitiveness: An analysis of determinant attributes. Journal of Travel Research, 50(1), 27-45.

Crouch, G. I., \& Ritchie J. R. (1999). Tourism, competitiveness, and social prosperity. Journal of Business Research, 44, 137-152.

De Moya, M., \& Jain, R. (2013). When tourists are your "friends": Exploring the brand personality of Mexico and Brazil on Facebook. Public Relations Review, 39(1), 23-29.

D’Hauteserre, A. M. (2000). Lesson in managed destination competitiveness: The case of Foxwoods Casino Resort. Tourism Management, 21, 23-32.

Di Pietro, L., Di Virgilio, F., \& Pantano, E. (2012). Social network for the choice of tourist destination: Attitude and behavioural intention. Journal of Hospitality and Tourism Technology, 3(1), 60-76.

Dickinson, J. E., Ghali, K., Cherrett, T., Speed, C., Davies, N., \& Norgate, S. (2014). Tourism and the smartphone app: Capabilities, emerging practice and scope in the travel domain. Current Issues in Tourism, 17(1), 84-101.

Dwyer, L., Forsyth, P., \& Dwyer, W. (2010). Tourism economics and policy. Bristol, UK: Channel View Publications.

Dwyer, L., \& Kim, C. (2003). Destination competitiveness: Determinants and indicators Current Issues in Tourism, 6(5), 369-414.

Dwyer, L., Liavic, Z. \& Mellor, R. (2003). Competitiveness of Australia as a tourist destination. Journal of Hospitality and Tourism Management, 10(1), 60-78. 
Edleman, D. (2010). Branding in the digital age: You're spending your money in all the wrong places. Harvard Business Review, 88(12), 62-69.

Enright, M. J., \& Newton, J. (2004). Tourism destination competitiveness: A quantitative approach. Tourism Management, 26(6), 777-788.

Exceltur. (2015). MoniTUR Monitor de Competitividad de Turística de las Comunidades Autónomas. Retrieved from https://www.exceltur.org/monitur/monitor-de-com petitividad-turistica-de-las-comunidades-autonomas 2014/

Filieri, R., Alguezaui, S., \& McLeay, F. (2015). Why do travelers trust TripAdvisor? Antecedents of trust towards consumer generated media and its influence on recommendation adoption and word of mouth. Tourism Management, 51, 174-185.

Gallarza, M. G., Gil-Saura, I., \& García, H. C. (2002). Destination image: Towards a conceptual framework. Annals of Tourism Research, 29(1), 56-78.

Garay, L. L., \& Cànoves, G. (2016). Barcelona: New stakeholders and new images in social media reviews. Tourism Analysis, 21(2-3), 287-292.

Gooroochurn, N., \& Sugiyarto, G. (2005). Competitiveness indicators in the travel and tourism industry. Tourism Economics, 11(1), 25-43.

Govers, R., \& Go, F. M. (2003). Deconstructing destination image in the information age. Information Technology \& Tourism, 6(1), 13-29.

Govers, R., Go, F. M., \& Kumar, K. (2007). Virtual destination image a new measurement approach. Annals of Tourism Research, 34(4), 977-997.

Gretzel, U., \& Yoo, K. H. (2008). Use and impact of online travel reviews. Paper presented at the International Conference on Information and Communication Technologies in Travel and Tourism, Innsbruck, Austria.

Gretzel, U., Werthner, H., Koo, C., \& Lamsfus, C. (2015). Conceptual foundations for understanding smart tourism ecosystems. Computers in Human Behavior, 50, 558-563.

Han, J.-H., \& Mills, J. E. (2006). Zero acquaintance benchmarking at travel destination websites: What is the first impression that national tourism organizations try to make? International Journal of Tourism Research, 8(6), 405-430.

Hassan, S. S. (2000). Determinants of market competitiveness in an environmentally sustainable tourism industry. Journal of Travel Research, 38, 239-245.

Hays, S. Page, S. J., \& Buhalis, D. (2013). Social media as a destination marketing tool: Its use by national tourism organisations. Current Issues in Tourism, 16(3), 211-239.

Heath, E. (2003). Towards a model to enhance destination competitiveness: A Southern African perspective. Journal of Hospitality and Tourism Management, 10(2), 124-141.

Hong, W. C. (2009). Global competitiveness measurement for the tourism sector. Current Issues in Tourism, 12(2), 105-132.
Horng, J. S., \& Tsai, C. T. S. (2010). Government websites for promoting East Asian culinary tourism: A crossnational analysis. Tourism Management, 31(1), 74-85.

Instituto Nacional de Estadística. (2016). Contabilidad Regional de España. Base 2010. Retrieved from http:// www.ine.es/daco/daco42/cre00/b2010/homog/dacocre_ base2010h.htm

Inversini, A., Cantoni, L., \& De Prieto, M. (2014). Destination online communication: Why less is sometimes more. A study of online communications of English destinations. Journal of Travel \& Tourism Marketing, 31(5), 563-575.

Kim, C., \& Lee, T. (2005). Exploring four dimensional sources of destination competitiveness. International Journal of Tourism Sciences, 5(1), 105-130.

Komsic, J., \& Dorcic, J. (2016). Tourism destination competitiveness and online reputation: Conceptualization and literature framework analysis. In Tourism \& Hospitality Industry 2016, Congress Proceedings (pp. 144-157). Opatua, Croatia: University of Rueka.

Kozak, M., \& Rimmington, M. (1999). Measuring tourist destination competitiveness: conceptual considerations and empirical findings. Hospitality Management, 18, 273-283.

La Caixa. (2014). Anuario Económico de España 2013. Retrieved from http://citythink.es/web/wp-content/uploads/ pdf/Anuario_economico_LaCaixa.pdf

Law, R., Qi, S., \& Buhalis, D. (2010). Progress in tourism management: A review of website evaluation in tourism research. Tourism Management, 31(3), 297-313.

Leung, R., \& Law, R. (2006). Information technology publications in leading tourism journals: A study of 1985-2004. Information Technology \& Tourism, 9(3), 133-144.

Leung, D., Law, R., Van Hoof, H., \& Buhalis, D. (2013). Social media in tourism and hospitality: A literature review. Journal of Travel \& Tourism Marketing, 30(1-2), 3-22.

Marchiori, E., \& Cantoni, L. (2011). The online reputation construct: Does it matter for the tourism domain? A literature review on destinations' online reputation. Information Technology \& Tourism, 13(3), 139-159.

Marine-Roig, E., \& Clavé, A. S. (2015). Tourism analytics with massive user-generated content: A case study of Barcelona. Journal of Destination Marketing \& Management 4(2015), 162-172.

Martin, D., Alzua, A., \& Lamsfus, C. (2011). A contextual geofencing mobile tourism service. In R. Law, M. Fuchs, \& F. Ricci (Eds.), Information and communication technologies in tourism 2011 (pp. 191-202). Vienna, Austria: Springer Verlag.

Martin, D. J., Jacobsen, J., \& Martin, L. (2011). Tourist perceptions of summer weather in Scandinavia. Annals of Tourism Research, 38(3), 920-940.

Miguéns, J., Baggio, R., \& Costa, C. (2008). Social media and tourism destinations: TripAdvisor case study. Advances in Tourism Research, 26(28), 26-28.

Mika, M. (2012). Competitiveness of tourist destinations as a research problem in the geography of tourism — analytical 
assumptions behind the research model. Prace Geograficzne, 130, 91-105.

Milano, R., Baggio, R., \& Piattelli, R. (2011). The effects of online social media on tourism websites. Paper presented in ENTER 2011 18th International Conference on Information Technology and Travel \& Tourism, January 26-28, Innsbruck, Austria.

Miličević, K., Mihalič, T., \& Sever, I. (2017). An investigation of the relationship between destination branding and destination competitiveness. Journal of Travel \& Tourism Marketing, 34(2), 209-221.

Munar, A. M., \& Jacobsen, J. K. S. (2013). Trust and involvement in tourism social media and web-based travel information sources. Scandinavian Journal of Hospitality and Tourism, 13(1), 1-19.

Munar, A. M., \& Jacobsen, J. K. S. (2014). Motivations for sharing tourism experiences through social media. Tourism Management, 43, 46-54.

Neuts, B., Romão, J., Nijkamp, P., \& Van Leeuwen, E. (2013). Digital destinations in the tourist sector: A path model for the impact of e-services on tourist expenditures in Amsterdam. Letters in Spatial and Resource Sciences, 6(2), 71-80.

Oh, M., Kim, S., \& Lee, A. (2013). Development of an evaluation scale for inter-country tourism industry competitiveness using the Delphi technique and analytic hierarchy process. International Journal of Tourism Sciences, 13(2), 1-32.

Omerzel, D., \& Mihalic, T. (2008). Destination competitiveness-Applying different models, the case of Slovenia. Tourism Management, 29, 294-307.

Papatheodorou, A. (2002). Exploring competitiveness in Mediterranean resorts. Tourism Economics, 8(2), 133-150.

Pechlaner, H., Smeral, E., \& Matzier, K. (2002). Customer value management as a determinant of the competitive position of tourism destinations. Tourism Review, 57(4), 15-22.

Perles, J., Ramón, A. \& Sevilla, M. (2011). Determinants of the competitive advantage of residential tourism destinations in Spain. Tourism Economics, 17(2), 373-403.

Perles, J., Ramón, A. \& Sevilla, M. (2014). La cuota de mercado como indicador de competitividad en los destinos turísticos: Sentido y limitaciones. Cuadernos de Turismo, 34, 265-285.

Perles, J. Ramón, A. Rubia, A., \& Moreno, L. (2016). Economic crisis and tourism competitiveness in Spain: Permanent effects or transitory shocks? Current Issues in Tourism, 19(12), 1210-1234.

Perles, J. Ramón, A. Sevilla, M., \& Rubia, A. (2016). The effects of economic crises on tourism success: An integrated model. Tourism Economics, 22(2), 417-447.

Pike, S. (2002). Destination image analysis_a review of 142 papers from 1973 to 2000. Tourism Management, 23(5), 541-549.

Pike, S., \& Mason, R. (2011). Destination competitiveness through the lens of brand positioning: The case of Australia's Sunshine Coast. Current Issues in Tourism, 14(2), 169-182.
Poon, A. (1993). Tourism, technology, and competitive strategy. Wallingford, UK: CAB International.

Porter, M. (1990). The competitive advantage of nations. New York, NY: Free Press.

Prayag, G. (2008). Image, satisfaction and loyalty - the Case of Cape Town. Anatolia: An International Journal of Tourism and Hospitality Research, 19(2), 205-224.

Prayag, G., \& Ryan, C. (2011). Antecedents of tourists' loyalty to Mauritius: The role and influence of destination image, place attachment, personal involvement, and satisfaction. Journal of Travel Research, 51(3), 342-356.

Rajesh, R. (2013). PASOS. Revista de Turismo y Patrimonio Cultural, 11(3) [Special Issue].

Rita, P. (2000). Web marketing tourism destinations. Paper presented at The 8th European Conference on Information Systems (ECIS), July 3-5, at Vienna, Austria.

Rodríguez-Díaz, M., \& Espino-Rodríguez, T. F. (2018). A methodology for a comparative analysis of the lodging offer of tourism destinations based on online customer reviews. Journal of Destination Marketing \& Management, 8, 147-160.

Sigala, M. (2011). eCRM 2.0 applications and trends: The use and perceptions of Greek tourism firms of social networks and intelligence. Computers in Human Behavior, 27(2), 655-661. doi: https://doi.org/10.1016/j.chb. 2010.03.007.

Singer, P., Ferri, M., Aiello, L., \& Cacia, C. (2010). Internet as a "point of synergy" between communication and distribution: Hypothesis of model applied to tourism. International Journal of Digital Content Technology and its Application, 4(7), 23-37.

Socialvane. (2016). Ranking big data de costas e islas españolas. Retrieved from https://www.hosteltur.com/115329_ ranking-big-data-costas-islas-espanolas.html

Sonmez, S., \& Sriakaya, E. (2002). A distorted destination image? The case of Turkey. Journal of Travel Research, 41, 185-196.

Spence, A., \& Hazard, H. (1988). International competitiveness. Cambridge, MA: Ballinger Publishing Company.

Stamboulis, Y., \& Skayannis, P. (2003). Innovation strategies and technology for experience-based tourism. Tourism Management, 24(1), 35-43.

Statista. (2018). Distribucion of social media used in Spain 2016-2017. Retrieved from https://www.statista.com/ statistics/570079/distribution-of-social-media-usedspain/

Vengesayi, S. (2003). A conceptual model of tourism destination competitiveness and attractiveness. In R. Kennedy (Ed.), Proceedings of the 2003 ANZMAC Conference (pp. 637-645). Adelaide, Australia: ANZMAC.

Werthner, H. (2003). Intelligent systems in travel and tourism. In IJCAI'03 Proceedings of the 18th International Joint Conference on Artificial Intelligence (pp. 1620-1625). San Francisco, CA: Morgan Kaufmann Publishers.

World Economic Forum. (2015). Travel and tourism competitiveness report 2015: Growth through shocks. Geneva, Switzerland: Author. 
Zach, F., Marchiori, E. \& Cantoni, L. (2012). Web Marketing and Social Media: The case of Adoption and Outsourcing by Swiss DMOs. Presented at 2012 TTRA International Conference Tourism Travel and Research Association: Advancing Tourism Research Globally. Retrieved from http://scholarworks.umass.edu/ttra/2012/Oral/17
Zhang, H., Fu, X., Cai, L. A., \& Lu, L. (2014). Destination image and tourist loyalty: A meta-analysis. Tourism Management, 40, 213-223. 
Copyright of Tourism Analysis is the property of Cognizant, LLC and its content may not be copied or emailed to multiple sites or posted to a listserv without the copyright holder's express written permission. However, users may print, download, or email articles for individual use. 